intention to keep Britain's defence strong, and also to strengthen the Atlantic Alliance and to endeavour to create more effective means by which the United Nations could step in to keep the peace and prevent small clashes from escalating into big ones. Equally it was its intention to take initiatives in disarmament whenever the opportunity arose or could be created.

This clear intention to keep disarmament in the forefront implies some consideration of the consequences of disarmament as well as of the means by which it can be achieved. The increased attention which is now being directed generally to those economic and social consequences may indicate that, dospite all the technical and political difficulties, practical steps towards disarmament are not so remote as would at first appear. Taken with the Primo Minister's firm assertions on defence, the organization which the Government is establishing should help to ensure that when the time is ripe Britain is prepared with the economic and social measures which must be the counterpart of any reduction in armaments. One preparatory step must be the education of public opinion for the necessary changes, and in this connexion it is significant as well as welcome that the November 1964 issue of The Unesco Courier, which contains the text of the Nuclear Test Ban Treaty of August 1963, includes also several articles on these social and economic aspects of disarmament.

\section{THE FOUNDER OF MODERN ATOMIC PHYSICS}

\section{J. J. Thomson and the Cavendish Laboratory in his Day}

By Sir George Paget Thomson. (British Men of Science.) Pp. xi $+186+20$ plates. (London and Edinburgh: Thomas Nelson and Sons, Ltd., 1964.) 25s. net.

$\mathrm{T}$ HIS short biography of Sir J. J. Thomson by his son is one of a series on British Men of Science intended for the general reader.

'J.J.' entered Owens College, soon to become the Victoria University of Manchester, at the early age of fourteon and studied engineering, mathematics, physics and chemistry - Owens being one of the few Colleges with a physies laboratory at that time. At the age of nineteen he tried for a scholarship at Trinity College, Cambridge, but did not even qualify for an Exhibition. He tried again the following year and obtained a minor scholarship and sizarship and entered Trinity College to take the Mathematical Tripos at the age of twonty. At this time Clerk Maxwell was Cavendish professor. J.J. became socond Wrangler and second Smith's prizeman, with Joseph Larmor in the lead. At the early age of twenty-eight, he succeoded Rayleigh as Cavendish professor and began work on the discharge of electricity through rarefied gases. This was a time when Hertz, Lenard, Perrin, Schuster and Wiechert were experimenting with the cathode rays. The discovery of X-rays by Roentgen in 1895 led J.J. to work on the ionizing properties of the X-rays. He then moved on to his successful measurement of $e / m$ for the electron. Hertz had tried this experiment but failed, and J.J. was successful entirely because of the improved vacuum he was able to produce by using the better vacuum pumps then available due to the development of the electric lamp industry -an interesting example of feed-back from technology. Working in the Cavendish in those days were Townsend, C. T. R. Wilson and Rutherford, newly arrived from New Zealand and soon to go on to MeGill University. The Laboratory staff included such characters as W. G. Pye, later to found Pye Instrument Company, Everett-
J.J.'s assistant-Hayles, who in later yoars became Rutherford's book-keeper/secretary in the Cavendish of the 1920's, and Lincoln, famous for his moustaches, the laboratory steward of the 1920's. F. W. Aston, who workod with J. J. Thomson in later years, said: "Working under him never lacked thrills. When results were coming out woll, his boundless, indeed childlike, enthusiasm was contagious and occasionally embarrassing. Negatives just developed had actually to be hidden away for fear ho would handle them while they were still wet, yet when hitches occurred and the exasperating vagaries of an apparatus had reduced a man who designed, built and worked with it to baffled despair, along would shuffle this remarkable being, who, after cogitating in the characteristic attitude over his funny old desk in the corner and jotting down a few figures and formula in his tiny handwriting on the back of somebody's Fellowship thesis or an old envelope or even the laboratory cheque book, would produce a luminous suggestion like a rabbit out of a hat, not only revealing the cause of the trouble but also the means of a cure."

Another chapter describes J.J.'s work on positive rays and isotopes, which was started in 1905, following Wien's work on the measurement of $e / m$ for the 'canal rays' discovered by Goldstein in 1866. J.J.'s improved vacuum technique led to his well-known parabolas and to the separation of the neon isotopes and thence to the mass spectrograph.

The author refers to the discussions at Farnboroughnow the Royal Aircraft Establishment, Farnboroughin mid-1915 between Aston and Lindemann on whether the 22 parabola was due to $\mathrm{NoH}_{2} \cdot \mathrm{CO}_{2}$. Lindemann always won the argument but "Aston had faith and was unbeatable". He returned to the Cavendish after the First World War to prove this by his mass spectrograph.

J.J. founded the Cavendish Physical Society for weekly discussions of laboratory experimental work, interspersed with lectures by visiting scientists; also the Cavendish tea-hour which was and is an occasion for general conversation rather than scientific discussion.

J.J. was interested in cricket, especially Lancashire cricket, and was also a keen supporter of the University Rugby Club. His greatest hobby was flowers, both wild and cultivated, and he made yearly pilgrimages to places near Cambridge when favourite flowers were in bloom.

In 1918 J.J. became Master of Trinity and handed over the Cavendish professorship to Rutherford, but continued to work in the part of the laboratory known as "the Garage". Here his assistant Everett presided over and erected variations of the maze of glass tubing where his experimonts were carried out and J.J. appeared punctually at $1.00 \mathrm{p} . \mathrm{m}$. every day to hear about the results of the oxperiments. He continued to lecture in the Cavendish, but his views of physics were by now rather conservative.

During the First World War he was chairman of a Royal Commission set up to report on the position of Natural Science in the educational system of Britain. Many of his views are still relevant to-day. He felt that the famous schools were too apt to temp's boys into classics at an early age by their system of scholarships. He valued an education which retained the boys' interest and freshness. Evidence was presented to tho Royal Commission that boys who were to compete for entrance scholarships did little in the two years before the examina. tion other than write out answers to papers set in previous examinations. Under this system the boys became more and more fed up with mathematics the more they persevered with it. Ho believed that some teaching was a positive advantage to a man's research and that interruptions at the right time helped original thought.

Sir George Thomson's biography gives a good account of a very great scientist.
J. CockCROFT 